\title{
Assessment of Pre and Postoperative Voiding Habits among Patients Undergoing Prostatectomy
}

\author{
Reham Hanafy Mahmoud Ouda ${ }^{1}$, Zeinab Hussein Ali ${ }^{2}$, Manal Hamed Mahmoud ${ }^{3}$ and \\ Amal Saied Taha 4
}

(1) Nursing Supervisor of the Intensive Care Unit at Damanhur Fever Hospital, (2) Professor and Head of Adult Health Department-Faculty of Nursing-Helwan University, Egypt (3) Professor of Medical Surgical Nursing - Faculty of Nursing-Benha University- Egypt and (4) Assistant professor of Medical Surgical Nursing - Faculty of Nursing-Benha University- Egypt

\section{Abstract}

Background: Prostatectomy is a common procedure to remove the prostate gland, most often for prostate adenocarcinoma, although occasionally performed for benign prostatic hyperplasia. This study aimed to: Assess the pre and postoperative voiding habits among patients undergoing prostatectomy. Research design: Descriptive research design was utilized in carrying out this study. Setting: The study was conducted at Benha University Hospital in Urology Department. Subjects: The study was conducted on 105 patients undergoing prostatectomy. Study tools: Data were collected by using two tools I: Structured interviewing assessment to assess, patients' socio-demographic characteristics, patients' clinical information, and life style changes characteristics. II: Pre and postoperative voiding habits questionnaire Results: $40.0 \%$ of the studied patients aged 50 years old and more. $66.7 \%$ of them had total healthy lifestyle score. There were highly statistically significant differences in all items related the studied patients' voiding habits between pre and postoperative. There were highly statistically significant positive correlations between the studied patients' voiding habits and their lifestyle characteristics. Conclusion: There were highly statistically significant differences in all items related the studied patients' voiding habits between pre and postoperative. There were highly statistically significant positive correlations between the studied patients' voiding habits and their lifestyle characteristics related to dietary habits, smoking habits, personal hygiene, stress, and sexual practices. While there were no statistically positive correlations between the studied patients' voiding habits and their activities as well as exercises, sleep and comfort. Recommendations: This study recommended conducting a study on the aspects of patients and knowledge, attitude, and practices towards prostate cancer. Establishing of an educational program to improve health related quality of life for prostate cancer patients. The same study should be replicated for a large sample size from different geographical areas to generalize the results.

Key words: Preoperative, Postoperative, Voiding Habits, Prostatectomy \& Patients.

\section{Introduction}

The prostate is a walnut-sized reproductive organ located caudal to the bladder and cranial to the penis. As an exocrine gland, the prostate produces seminal fluid that nourishes and facilitates the transport of sperm (produced in the testicles) during and after ejaculation (Ferlay et al., 2020).
Various factors as age, genetics, environmental toxins, chemical hazards and radiations seem to be involved in the pathogenesis of prostate cancer but the exact mechanism is still unknown (Mei et al., 2020).

The complications of prostate tumor usually occur once the prostate has become large enough for affect the urethra, it may take many years 
because prostate tumor is generally slow growing (Mandal, 2020).

Treatment protocols were being practiced for reduce the above-mentioned risk of prostate tumor, and no treatment is required for benign stage tumor. Moreover, in the case of metastatic invasion, surgery can be opted for remove prostate and associated tissues and lymph nodes. Radiation external beam radiations and internal radiations (brachytherapy) (Fujita et al., 2020).

\section{Significance of the study:}

Prostate tumor is the second most frequent malignancy in men worldwide, counting 1,276,106 new cases and causing 358,989 deaths in 2018. The incidence and mortality of prostate tumor worldwide correlate by increasing age by the average age at the time of diagnosis being 66 years. Although 2,293,818 new cases were estimated until 2040, a small variation in mortality will be observed an increase of $1.05 \%$ (Barsouk et al., 2020).

\section{Aim of the study:}

The aim of it study was for assess the pre and postoperative voiding habits among patients undergoing prostatectomy.

\section{Research questions:}

1. What is the effect of prostatic tumor on the pre and postoperative voiding habits among patients undergoing prostatectomy?

2. What is the life style patterns effect on the voiding habits among patients undergoing prostatectomy?

\section{Subject and Method}

\section{Research design:}

Descriptive research design was utilized in carrying out this study.

\section{Setting:}

The study was conducted at Benha University Hospital in Urology Department it consists of 36 beds for patients and included 25 nurses.

\section{Subjects:}

The study was conducted on 105 patients undergoing prostatectomy. The sample size represented $30 \%$ from the total number of cases who attended for the Urology Department at Benha University Hospital in the year of 2017 as the total number of patients have prostate tumor was 350 patients, according for the data obtained from the report of Benha University Hospital statistical office (2017).

\section{Tools of data collection:Two tool were used}

Tool I:-Structured interviewing assessment sheet: - It was developed by the researcher based on reviewing the related literatures and it was written in a simple clear Arabic language, and consisted of the following parts:

Part I: A- Socio-demographic characteristics of the studied patients. It included eight questions related age, educational level, marital status, family size, and occupation, type of job, monthly income, and residence.

B- Patients' clinical information (physical nutrition assessment). It included three questions related for length, weight, and Body Mass Index (BMI).

Part II: - The medical history and included two items:

A- The medical history. It included five questions related for hospitalization due for prostate enlargement, the reason for admission, symptoms patients complain from, the duration of symptoms, and the methods used for overcome the symptoms.

B- The past medical history. It included fourteen questions related the presence of chronic diseases, the type of chronic diseases, the presence of urinary system problems, the type of the problems, how often the problem 
occurred, the previous treatment for the problem, the frequency of medication used, the regularity for taking the medication, causes of not taking the medication, taking the medication without prescription, the name of medications, the person prescribing the medication, and the use of herbal medicine in the treatment of prostate enlargement, and the type of herbal used.

Part III: - The patients' life style changes characteristics; It composed of Likert like scale by three responses for each item usually, sometimes, and never it included (46 sub items) distributed in seven main items as the following; dietary habits it contained (19 items), activities, and exercises it contained (5 items), smoking habit it contained (5 items), personal hygiene it contained (4 items), sleep and comfort it contained (6 items), stress it contained (4 items), and sexual practices it contained (3 items).

\section{- Scoring system:}

Scores for each response on questions was given as follow:

$$
\begin{aligned}
& 2=\text { Usually } \\
& 1=\text { Sometimes } \\
& 0=\text { Never } \\
& \text { total score of items }=92
\end{aligned}
$$

The score of all items was summed-up and the total divided by the number of the items, and multiplied by one hundred. These scores were converted into a percent. The lifestyle was considered healthy if the total score is $>80 \%$ (> 73 point), while considered unhealthy if it is $<80 \%$ ( $<73$ points $)$.

Tool II: Pre and postoperative voiding habits questionnaire: It was developed by the researcher based on reviewing the related literatures, it was written in a simple clear Arabic language. It consisted of two main items; the preoperative voiding habits it contained (10 items), and the postoperative voiding habits it contained (10 items).

\section{- Scoring system:}

The scoring system was 1 for Yes answer and 2 for No answer.

Reliability of the tool was done by using Cronbach's Alpha coefficient test it revealed to each of the two tools consisted of relatively homogenous items as indicated by high reliability for each tool.

\section{Ethical considerations:}

A written /oral consent was obtained from the studied patients in order for participate in the study. The aim of the study explained for all the patients and they were assured that all information will be confidential and used only for the research purpose. The studied patients reassured that they have the right for withdraw from the study at any time.

\section{Statistical design:}

Statistical analysis was done by using Statistical Package for Social Sciences (SPSS) version 22. Data were collected, revised, coded, organized, tabulated, and analyzed using frequencies, number, percentage, mean scores, standard deviation. Data were presented in the form of tables and figures. Quantitative data was presented by mean $(\overline{\mathrm{X}})$ and standard deviation (SD).

Qualitative data was presented in the form of frequency distribution tables, number and percent. It was analyzed by Chi- square test $\left(\mathrm{X}^{2}\right)$ for detect the relation between the variables of the study (P-value).

Statistical significance was considered as follows:

- P-value $>0.05 \quad$ Not significant

$\bullet$ P-value < 0.05 Significant

- P-value $<0.001$ Highly significant 


\section{Results:}

Table (1): Shows that, $40.0 \%$ of the studied patients aged 50 years old and more by a mean age and standard deviation of $46.63 \pm 10.99$, $38.1 \%$ of them had diploma/secondary education, and $54.3 \%$ of them were married. Regarding the family size, $69.5 \%$ of the studied patients had more than five members in their family, and $78.1 \%$ of them were working. Concerning the type of job, $61.0 \%$ of the working patients had a manual technical work, and $70.7 \%$ of them had enough monthly income.

Table (2): Clarifies that, $56.2 \%$ of the studied patients had length between 171 for $180 \mathrm{~cm}$ by a mean length of $174.23 \pm 5.11,32.4 \%$ of their weight had more than $100 \mathrm{~kg}$ by mean weight of $93.84 \pm 12.51$, and $42.9 \%$ of their BMI ranged between 32 for 38 by mean of $29.25 \pm 4.42$.

Table (3): Demonstrates that, $30.5 \%$ of the studied patients hospitalized due to prostate enlargement only once, $27.6 \%$ of them hospitalized twice, while $23.8 \%$ of them hospitalized more than twice because all of them $100.0 \%$ were unable for urinate. Regarding the symptoms it they were suffering from, all of them $100 \%$ had poor urine flow rate, and $93.0 \%$ had burning sensation during urination. Respecting the duration of symptoms, $88.4 \%$ of the studied patients were suffering from these symptoms for few days, and $93.0 \%$ of them consult the doctor for overcome them.

Figure (1): Illustrates that, $35.7 \%$ of the studied patients were suffering from hypertension, while $28.6 \%$ of them had diabetes millets.

Table (4): Shows that, $27.8 \%$ of the studied patients didn't take the medication regularly because they forgot it, and $63.9 \%$ of them were taking the medications without prescription. Concerning the type of medication used, $65.2 \%$ of the studied patients were taking flummox, while all of them $100.0 \%$ were taking the medication by themselves, and $73.3 \%$ of them were using herbal medicine in the treatment of prostate enlargement.

Figure (2): Denotes that, $64.9 \%$ of the studied patients were using Ginger in the treatment of prostate enlargement, while $35.1 \%$ of them were using Aloe Vera.

Figure (3): Shows it, $66.7 \%$ of the studied patients had total healthy lifestyle score, while $33.3 \%$ of them had total unhealthy lifestyle score.

Table (5): Describes that, $89.5 \%, 84.8 \%$, and $83.8 \%$ of the studied patients were taking long time for empty their bladder, pushing and straining for urinate, and unable for completely void their bladder preoperative it decreased for $27.6 \%, 34.3 \%$, and $40.0 \%$ postoperative respectively. There were highly statistically significant differences in all items related the studied patients' voiding habits between pre and postoperative $(\mathrm{P}<0.001)$.

Table (6): Describes that there were highly statistically significant differences between the studied patients' total lifestyle score and their socio-demographic characteristics regarding age, educational level, marital status, and family size $(\mathrm{P} \leq 0.001)$, and there was statistically significant difference regarding the monthly income $(\mathrm{P} \leq 0.05)$, while there was no statistically significant difference regarding occupation ( $\mathrm{P}>0.05)$.

Table (7): Shows that there were highly statistically significant positive correlations between the studied patients' voiding habits and their lifestyle characteristics related to dietary habits, smoking habits, personal hygiene, stress, and sexual practices. While there were no statistically positive correlations between the studied patients' voiding habits and their activities as well as exercises, sleep and comfort. 
Table (1): Distribution of the studied patients according their socio-demographic characteristics, $(\mathbf{n}=\mathbf{1 0 5})$.

\begin{tabular}{|c|c|c|}
\hline Socio-demographic characteristics & No. & $\%$ \\
\hline \multicolumn{3}{|l|}{ Age (years): } \\
\hline $20-$ & 7 & 6.7 \\
\hline $30-$ & 22 & 20.9 \\
\hline $40-$ & 34 & 32.4 \\
\hline $50+$ & 42 & 40.0 \\
\hline \multicolumn{3}{|l|}{$\overline{\mathbf{X}} \pm$ SD $\quad 46.63 \pm 10.99$} \\
\hline \multicolumn{3}{|l|}{ Educational level: } \\
\hline Illiterate & 31 & 29.5 \\
\hline Read and write & 15 & 14.3 \\
\hline Diploma/Secondary education & 40 & 38.1 \\
\hline University education & 19 & 18.1 \\
\hline \multicolumn{3}{|l|}{ Marital status: } \\
\hline Single & 10 & 9.5 \\
\hline Married & 57 & 54.3 \\
\hline Divorced & 20 & 19.0 \\
\hline Widowed & 18 & 17.1 \\
\hline \multicolumn{3}{|l|}{ Family size: } \\
\hline$<3$ & 11 & 10.5 \\
\hline $3-$ & 21 & 20.0 \\
\hline $5+$ & 73 & 69.5 \\
\hline \multicolumn{3}{|l|}{ Occupation: } \\
\hline Work & 82 & 78.1 \\
\hline Don't work & 23 & 21.9 \\
\hline \multicolumn{3}{|l|}{ Type of job $(n=82):$} \\
\hline Mental work & 32 & 39.0 \\
\hline Manual technical work & 50 & 61.0 \\
\hline \multicolumn{3}{|l|}{ Monthly income (n=82): } \\
\hline Enough & 58 & 70.7 \\
\hline Not enough & 24 & 29.3 \\
\hline
\end{tabular}


Table (2): Distribution of the studied patients according their anthropometric measurements, (n = 105).

\begin{tabular}{|c|c|c|}
\hline Patients' clinical information items & No. & $\%$ \\
\hline \multicolumn{3}{|l|}{ Length $(\mathrm{Cm})$ : } \\
\hline $160-170$ & 33 & 31.4 \\
\hline $171-180$ & 59 & 56.2 \\
\hline $181-190$ & 13 & 12.4 \\
\hline \multicolumn{3}{|l|}{$\overline{\mathrm{X}} \pm \mathrm{SD} 174.23 \pm 5.11$} \\
\hline \multicolumn{3}{|l|}{ Weight (Kg): } \\
\hline $70-80$ & 12 & 11.4 \\
\hline $81-90$ & 27 & 25.7 \\
\hline $91-100$ & 32 & 30.5 \\
\hline $100+$ & 34 & 32.4 \\
\hline \multicolumn{3}{|l|}{$\overline{\mathbf{X}} \pm$ SD $\quad 93.84 \pm 12.51$} \\
\hline \multicolumn{3}{|l|}{ Body Mass Index (BMI): } \\
\hline $18.5-24.9$ & 24 & 22.9 \\
\hline $25-31$ & 35 & 33.3 \\
\hline $32-38$ & 45 & 42.9 \\
\hline $38+$ & 1 & 0.9 \\
\hline \multicolumn{3}{|l|}{$\overline{\mathbf{X}} \pm$ SD $29.25 \pm 4.42$} \\
\hline
\end{tabular}


Table (3): Distribution of the studied patients according their present health history, $(\mathrm{n}=105)$.

\begin{tabular}{|c|c|c|}
\hline Patients' present health history & No. & $\%$ \\
\hline \multicolumn{3}{|c|}{ Have you ever been hospitalized due for prostate enlargement? } \\
\hline No & 19 & 18.1 \\
\hline Once & 32 & 30.5 \\
\hline Twice & 29 & 27.6 \\
\hline More than twice & 25 & 23.8 \\
\hline \multicolumn{3}{|l|}{ The reason for admission $(n=86)$ : } \\
\hline Unable for urinate & 86 & 100.0 \\
\hline Hematuria & 70 & 81.4 \\
\hline \multicolumn{3}{|l|}{ What are the symptoms you feel it now? $(n=86)$ : } \\
\hline Increase the number of urination at night & 20 & 23.3 \\
\hline Increase the number of urination during the day & 27 & 31.4 \\
\hline Urine retention & 60 & 69.8 \\
\hline Poor urine flow rate & 86 & 100.0 \\
\hline Urinary incontinence & 50 & 58.1 \\
\hline Hematuria & 70 & 81.4 \\
\hline Squeezing during urination & 77 & 89.5 \\
\hline Burning sensation during urination & 80 & 93.0 \\
\hline \multicolumn{3}{|c|}{ How long have you been feeling these symptoms? $(n=86)$ : } \\
\hline Days & 76 & 88.4 \\
\hline Weeks & 10 & 11.6 \\
\hline \multicolumn{3}{|l|}{ What you done for overcome this symptoms ? $(n=86)$ : } \\
\hline Adhere for a healthy diet & 33 & 38.4 \\
\hline Avoid smoking & 55 & 64.0 \\
\hline Take analgesic & 60 & 69.8 \\
\hline Others (specify) Doctor consultation & 80 & 93.0 \\
\hline
\end{tabular}

* Responses were not mutually exclusive

\section{The patients' chronic diseases}

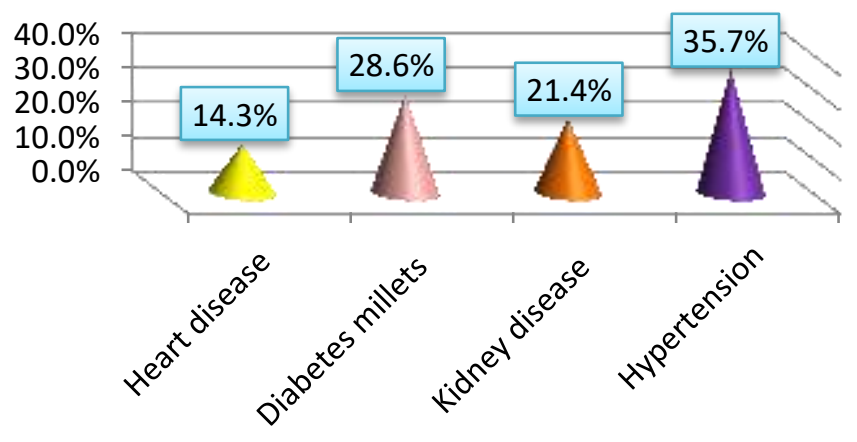

Figure (1): Distribution of the studied patients according for their chronic diseases, $(n=70)$. 
Table (4): Distribution of the studied patients according their past health history, $(n=105)$.

\begin{tabular}{|c|c|c|}
\hline The patients' past health history & No. & $\%$ \\
\hline \multicolumn{3}{|l|}{ Were you regularly taking these medications? $(n=36)$} \\
\hline Yes & 26 & 72.2 \\
\hline No & 10 & 27.8 \\
\hline \multicolumn{3}{|l|}{ If the answer is no, why? } \\
\hline Forget it & 10 & 27.8 \\
\hline \multicolumn{3}{|c|}{ Do you take medications without a prescription? $(n=36)$} \\
\hline Yes & 23 & 63.9 \\
\hline No & 13 & 36.1 \\
\hline \multicolumn{3}{|l|}{ If yes, what were these medications? $(n=23)$} \\
\hline Minipress & 3 & 13.0 \\
\hline Flumox & 15 & 65.2 \\
\hline Tamsulin & 5 & 21.8 \\
\hline \multicolumn{3}{|l|}{ The previous medications mentioned were taking by: } \\
\hline Your self & 23 & 100.0 \\
\hline \multicolumn{3}{|c|}{ Using of herbal medicine for treat prostate enlargement? } \\
\hline Yes & 77 & 73.3 \\
\hline No & 28 & 26.7 \\
\hline
\end{tabular}

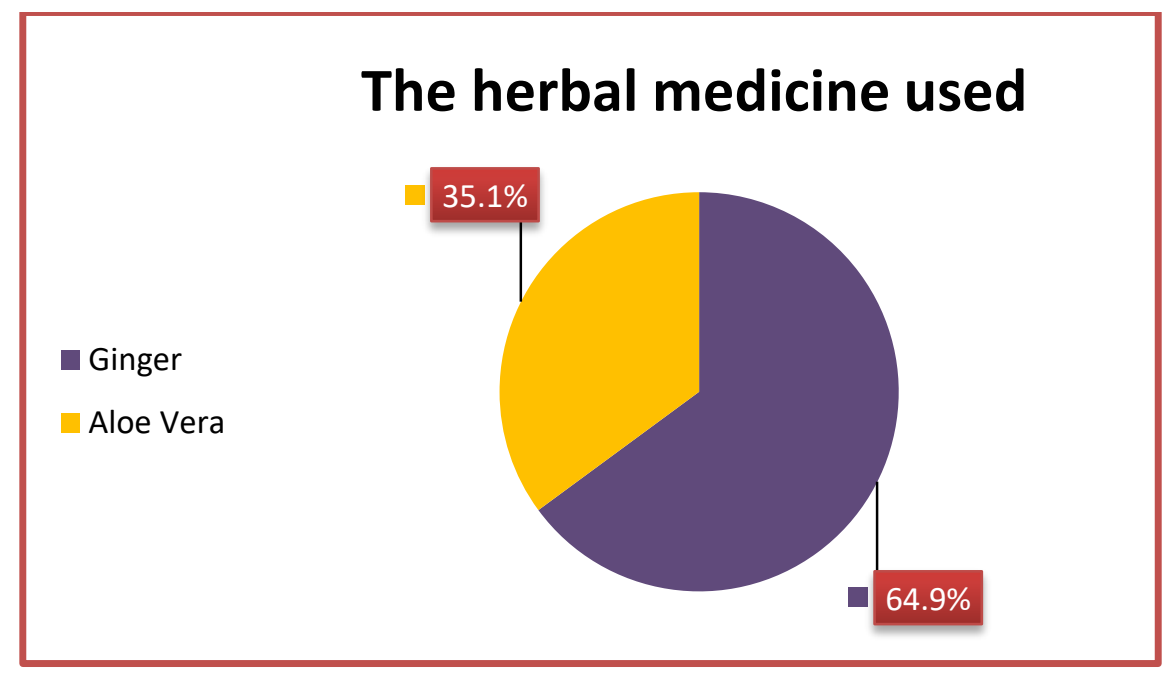

Figure (2): Distribution of the studied patients according their use for herbal medicine in the treatment of prostate enlargement, $(n=77)$. 


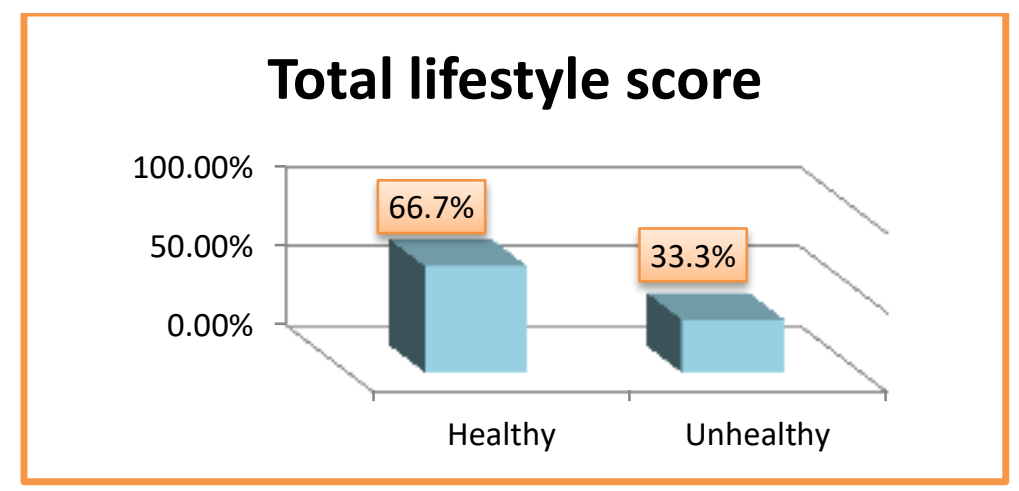

Figure (3): Distribution of the studied patients according their total lifestyle score, $(n=105)$.

Table (5): Distribution of the studied patients according their pre and postoperative voiding habits, $(\mathbf{n}=105)$.

\section{Voiding habits items}

\begin{tabular}{|c|c|c|c|c|c|}
\hline \multicolumn{2}{|c|}{ Preoperative } & \multicolumn{2}{c|}{ Postoperative } & \multicolumn{2}{c|}{ Significance test } \\
\hline No. & $\%$ & No. & $\%$ & $\chi^{2}$ & P-value \\
\hline
\end{tabular}

1- Go for toilet more than 5 - 8 times in 24hours:

\begin{tabular}{||l|r|c|c|c|c|c|}
\hline Yes & 71 & 67.6 & 30 & 28.6 & 87.70 & $0.001 * *$ \\
\hline No & 34 & 32.4 & 75 & 71.4 & & \\
\hline 2- Get up more than once a night: \\
Yes & 85 & 80.9 & 40 & 38.1 & 15.20 & $0.001 * *$ \\
\hline No & 20 & 19.1 & 65 & 61.9 & & \\
\hline
\end{tabular}

3- Wet yourself when you cough, laugh, sneeze or exercise:

\begin{tabular}{|c|c|c|c|c|c|c|}
\hline Yes & 70 & 66.7 & 37 & 35.2 & \multirow[t]{2}{*}{42.84} & \multirow[t]{2}{*}{$0.001 * *$} \\
\hline No & 35 & 33.3 & 68 & 64.8 & & \\
\hline \multicolumn{7}{|c|}{ 4- Have an urgent need for pass urine: } \\
\hline Yes & 80 & 76.2 & 41 & 39.0 & \multirow[t]{2}{*}{41.41} & \multirow[t]{2}{*}{$0.001 * *$} \\
\hline No & 25 & 23.8 & 64 & 61.0 & & \\
\hline
\end{tabular}

5- Leak before you get for the toilet:

\begin{tabular}{|c|c|c|c|c|c|c|}
\hline Yes & 77 & 73.3 & 33 & 31.4 & \multirow{2}{*}{17.50} & \multirow{2}{*}{$0.001^{* *}$} \\
\cline { 1 - 6 } No & 28 & 26.7 & 72 & 68.6 & & \\
\hline 6. Push
\end{tabular}

6- Push and strain for urinate:

\begin{tabular}{|c|c|c|c|c|c|c|}
\hline Yes & 89 & 84.8 & 36 & 34.3 & \multirow[t]{2}{*}{10.27} & \multirow[t]{2}{*}{$0.001 * *$} \\
\hline No & 16 & 15.2 & 69 & 65.7 & & \\
\hline \multicolumn{7}{|c|}{ 7- Take long time for empty bladder: } \\
\hline Yes & 94 & 89.5 & 29 & 27.6 & \multirow[t]{2}{*}{17.59} & \multirow[t]{2}{*}{$0.001 * *$} \\
\hline No & 11 & 10.5 & 76 & 72.4 & & \\
\hline \multicolumn{7}{|c|}{ 8- Unable for void without stimulus: } \\
\hline Yes & 78 & 74.3 & 38 & 36.2 & \multirow[t]{2}{*}{16.44} & \multirow[t]{2}{*}{$0.001 * *$} \\
\hline No & 27 & 25.7 & 67 & 63.8 & & \\
\hline \multicolumn{7}{|c|}{ 9- Increase urination at night: } \\
\hline Yes & 75 & 71.4 & 32 & 30.5 & \multirow[t]{2}{*}{24.01} & \multirow[t]{2}{*}{$0.001 * *$} \\
\hline No & 30 & 28.6 & 73 & 69.5 & & \\
\hline \multicolumn{7}{|c|}{ 10- Unable for completely void the bladder: } \\
\hline Yes & 88 & 83.8 & 42 & 40.0 & \multirow[t]{2}{*}{12.80} & \multirow[t]{2}{*}{$0.001 * *$} \\
\hline No & 17 & 16.2 & 63 & 60.0 & & \\
\hline
\end{tabular}


Table (6): Relation between the studied patients' total lifestyle score and their socio-demographic characteristics, $(n=105)$.

\begin{tabular}{|c|c|c|c|c|c|c|}
\hline \multirow{3}{*}{$\begin{array}{c}\text { Socio-demographic } \\
\text { characteristics }\end{array}$} & \multicolumn{6}{|c|}{ Total lifestyle score } \\
\hline & \multicolumn{2}{|c|}{ Healthy } & \multicolumn{2}{|c|}{ Unhealthy } & \multicolumn{2}{|c|}{ Significance test } \\
\hline & No. & $\%$ & No. & $\%$ & $\mathrm{X}^{2}$ & P-value \\
\hline \multicolumn{7}{|l|}{ Age (years): } \\
\hline $20-$ & 2 & 1.9 & 5 & 4.8 & \multirow{4}{*}{28.54} & \multirow{4}{*}{$0.001 * *$} \\
\hline $30-$ & 10 & 9.5 & 12 & 11.4 & & \\
\hline $40-$ & 15 & 14.3 & 19 & 18.1 & & \\
\hline $50+$ & 20 & 19.0 & 22 & 20.9 & & \\
\hline \multicolumn{7}{|l|}{ Educational level: } \\
\hline Illiterate & 10 & 9.5 & 21 & 20.0 & \multirow{4}{*}{49.09} & \multirow{4}{*}{$0.001 * *$} \\
\hline Read and write & 5 & & 10 & 9.5 & & \\
\hline $\begin{array}{c}\text { Diploma/Secondary } \\
\text { education }\end{array}$ & 18 & 17.1 & 22 & 20.9 & & \\
\hline University education & 8 & 7.6 & 11 & 10.5 & & \\
\hline \multicolumn{7}{|l|}{ Marital status: } \\
\hline Single & 4 & 3.8 & 6 & 5.7 & \multirow{4}{*}{19.36} & \multirow{4}{*}{$0.001 * *$} \\
\hline Married & 35 & 33.3 & 22 & 20.9 & & \\
\hline Divorced & 10 & 9.5 & 10 & 9.5 & & \\
\hline Widowed & 8 & 7.6 & 10 & 9.5 & & \\
\hline \multicolumn{7}{|l|}{ Family size: } \\
\hline$<3$ & 9 & 8.6 & 2 & 1.9 & \multirow{3}{*}{17.42} & \multirow{3}{*}{$0.001 * *$} \\
\hline $3-5$ & 6 & 5.7 & 15 & 14.3 & & \\
\hline $5+$ & 28 & 26.7 & 45 & 42.9 & & \\
\hline \multicolumn{7}{|l|}{ Occupation: } \\
\hline Work & 30 & 28.6 & 52 & 49.5 & \multirow{2}{*}{0.572} & \multirow{2}{*}{0.450} \\
\hline Don't work & 10 & 9.5 & 13 & 12.4 & & \\
\hline \multicolumn{7}{|l|}{ Monthly income (n=82): } \\
\hline Enough & 22 & 26.8 & 36 & 34.3 & \multirow[t]{2}{*}{12.40} & \multirow[t]{2}{*}{$0.012 *$} \\
\hline Not enough & 14 & 17.1 & 10 & 12.2 & & \\
\hline
\end{tabular}

No statistical significance $(\mathrm{P}>0.05)$

Statistically Significant $\quad(\mathrm{P} \leq 0.05)$
A highly statistical significant
$(\mathrm{P} \leq 0.001)$ 
Reham Hanafy Mahmoud Ouda, Zeinab Hussein Ali, Manal Hamed Mahmoud and Amal Saied Taha

Table (7): Correlation matrix between the studied patients' lifestyle characteristics and their voiding habits, $(\mathrm{n}=105)$.

\begin{tabular}{|c|c|c|c|c|c|c|c|c|}
\hline \multirow[b]{2}{*}{ Voiding habits items } & & \multicolumn{7}{|c|}{ Lifestyle items } \\
\hline & & $\begin{array}{l}\text { Dietary } \\
\text { habits }\end{array}$ & $\begin{array}{l}\text { Activities } \\
\text { and } \\
\text { exercises }\end{array}$ & $\begin{array}{c}\text { Smoking } \\
\text { habit }\end{array}$ & $\begin{array}{l}\text { Personal } \\
\text { hygiene }\end{array}$ & $\begin{array}{l}\text { Sleep } \\
\text { and } \\
\text { comfort }\end{array}$ & Stress & $\begin{array}{c}\text { Sexual } \\
\text { practices }\end{array}$ \\
\hline \multirow{2}{*}{$\begin{array}{l}\text { 1- Go for toilet more than } 5-8 \text { times in } \\
24 \text { hours. }\end{array}$} & $r$ & 0.261 & 0.149 & 0.075 & 0.288 & 0.098 & 0.290 & 0.497 \\
\hline & $\begin{array}{l}\mathrm{P}- \\
\text { value }\end{array}$ & $0.001 * *$ & 0.130 & 0.450 & $0.001 * *$ & 0.324 & $0.001^{* *}$ & $0.001 * *$ \\
\hline \multirow[b]{2}{*}{ 2- Get up more than once a night. } & $\mathrm{r}$ & $\cdot .937$ & $\cdot 206$ & $\cdot r \leqslant$. & 0.097 & 0.066 & 0.365 & 0.351 \\
\hline & $\begin{array}{l}\mathrm{P}- \\
\text { value }\end{array}$ & $\cdot .008 *$ & $\cdot .035$ & $.001 * *$ & 0.327 & 0.504 & $0.001 *=$ & $0.001 * *$ \\
\hline \multirow[b]{2}{*}{$\begin{array}{l}\text { 3-Wet yourself when you cough, laugh, } \\
\text { sneeze or exercise. }\end{array}$} & $\mathrm{r}$ & 0.084 & 0.137 & 0.083 & 0.172 & 0.120 & 0.085 & 0.229 \\
\hline & $\begin{array}{l}\mathrm{P}- \\
\text { value }\end{array}$ & 0.393 & 0.162 & 0.401 & 0.079 & 0.225 & 0.557 & 0.019 \\
\hline \multirow[b]{2}{*}{ 4- Have an urgent need for pass urine. } & $\mathrm{r}$ & 0.090 & 0.124 & 0.116 & 0.025 & 0.122 & 0.072 & 0.115 \\
\hline & $\begin{array}{l}\mathrm{P} \text { - } \\
\text { value }\end{array}$ & 0.360 & 0.206 & 0.238 & 0.801 & 0.216 & 0.468 & 0.244 \\
\hline \multirow[b]{2}{*}{ 5- Leak before you get for the toilet. } & $\mathrm{r}$ & 0.024 & 0.069 & 0.303 & 0.120 & 0.083 & 0.200 & 0.225 \\
\hline & $\begin{array}{l}\mathrm{P} \text { - } \\
\text { value }\end{array}$ & 0.804 & 0.487 & $0.002 * *$ & 0.223 & 0.403 & 0.041 & 0.021 \\
\hline \multirow[b]{2}{*}{ 6- Push and strain for urinate. } & $\mathrm{r}$ & 0.047 & 0.180 & 0.187 & 0.084 & 0.057 & 0.475 & 0.344 \\
\hline & $\begin{array}{l}\mathrm{P}- \\
\text { value }\end{array}$ & 0.632 & 0.066 & 0.057 & 0.392 & 0.562 & $0.001 *$ & $0.001 * *$ \\
\hline \multirow[b]{2}{*}{ 7- Take long time for empty bladder. } & $\mathrm{r}$ & 111 & 0.024 & 0.092 & 0.086 & 0.046 & 0.474 & 0.237 \\
\hline & $\begin{array}{l}\mathrm{P}- \\
\text { value }\end{array}$ & 0.260 & 0.810 & 0.351 & 0.490 & 0.645 & $0.001 * *$ & $0.015^{*}$ \\
\hline \multirow[b]{2}{*}{ 8- Unable for void without stimulus. } & $\mathrm{r}$ & 330 & 0.016 & 0.263 & 0.288 & 0.095 & 0.100 & 0.041 \\
\hline & $\begin{array}{l}\mathrm{P}- \\
\text { value }\end{array}$ & $0.001 * *$ & 0.871 & $0.001 * *$ & $0.001 * *$ & 0.335 & 0.308 & 0.679 \\
\hline \multirow[b]{2}{*}{ 9- Increase urination at night. } & $r$ & 0.029 & 0.045 & 0.259 & 0.144 & 0.100 & 0.070 & 0.312 \\
\hline & $\begin{array}{l}\mathrm{P}- \\
\text { value }\end{array}$ & 0.767 & 0.650 & $0.001 * *$ & 0.143 & 0.314 & 0.478 & $0.001 * *$ \\
\hline \multirow{2}{*}{$\begin{array}{l}\text { 10- Unable for completely void the } \\
\text { bladder. }\end{array}$} & $\mathrm{r}$ & 0.049 & 0.188 & 0.211 & 0.085 & 0.058 & 0.474 & 0.351 \\
\hline & $\begin{array}{l}\mathrm{P}- \\
\text { value }\end{array}$ & 0.624 & 0.056 & 0.032 & 0.389 & 0.560 & $0.001 *$ & $0.001 * *$ \\
\hline
\end{tabular}




\section{Discussion}

Prostate tumor is the second most frequently diagnosed tumor in men globally. Prostate tumor is marked by an uncontrolled (malignant) growth of cells in the prostate Prostatectomy considered as one of the most common treatment modalities for the disease and its effect on the patients' voiding habit. Functional outcomes following prostatectomy have a significant impact on quality of life (Canadian Cancer Society, 2021).

It study aimed for: assess the pre and postoperative voiding habits among patients undergoing prostatectomy.

Regarding age; the current study revealed; that less than half of the studied patients aged 50 years old. From the researchers' point of view, this result may be because it is the most commonly affected age by prostate tumor. This result agreed by Chin et al. (2017), they performed a study about "Long Term Illness Reported Urinary Function Following External Beam Radiotherapy for Prostatic Tumor Patients in England ", and found it nearly for half of the studied patients aged 50 years old and more.

This result and disagreed by Ahn et al. (2019), they conducted a study about "Improved Lower Urinary Tract Symptoms After Robot-assisted Radical Prostatectomy: Implications for Survivorship, Treatment Selection and Illness Counselling in Australia", and stated it majority of the studied patients' aged 65 year old and more.

More than two thirds of patients had more than five members in their family. From the researchers' point of view. This may be because the majority of peoples living in rural community always like for have a big family size.

This result was in the same line by Liu et al. (2020), they carried out a study about" Prognosis of Prostate Tumor and Bone Metastasis Pattern of Patients: A Local Hospital Based Study from China " and found it more than three quarters of the studied patients were living in rural areas and more than half of them had a big family size.

The present study results clarified that more than half of the studied patients were between 171 for $180 \mathrm{~cm}$ lengths by a mean length of $174.23 \pm 5$, less than one third of them their weight were more than $100 \mathrm{~kg}$ by mean weight of 93.84 \pm 12.51 , and less than half of them were overweight as their Body Mass Index ranged between 32 for 38 by mean of $29.25 \pm 4.42 \mathrm{~kg} / \mathrm{m}^{2}$, while the normal range of BMI is $18.5-24.9 \mathrm{~kg} / \mathrm{m}^{2}$. From the researchers' point of view, these results may be because the studied patients were not aware about the normal body BMI it may adversely affect their health outcome.

These results were in the same line by James et al. (2016), around one fourth of them their weight were between 100 for $110 \mathrm{~kg}$ by mean weight of $98.40 \pm 10.11$, and the mean of their Body Mass Index were $29.90 \pm 5.44 \mathrm{~kg} / \mathrm{m}^{2}$.

The present study results revealed that less than one third of the studied patients hospitalized for prostate enlargement only once, more than one fourth of them hospitalized twice, while less than one fourth of them hospitalized more than twice because all of them were unable for urinate. From the researchers' point of view, these results may be 
because the studied patients were suffering from chronic prostate enlargement.

All the studied patients had poor urine flow rate, while the majority of them had burning sensation during urination, and the majority of them were suffering from these symptoms for few days and, the majority of the studied patients consulted the doctor for overcome them. From the researchers' point of view, these results may be because it is the most common symptoms associated by prostate enlargement and consulting the doctor is the best way for overcome them.

These results supported by Tracy \& Kim (2020), they studied "Prostate Tumor Clinical Presentation in America", and found it the majority of the studied patients were suffering from urinary complaints or retention, burning micturition for more than three days and they consulted a specialist urology doctor for overcome these symptoms. While these results were inconsistent by

Less than two thirds of the studied patients were using Ginger, while more than one third of them were using Aloe Vera. From the researchers' point of view it may be because these herbals were able for reduce the body toxins and bacteria. These results agreed by Saxena, et al. (2020), they performed a study about " Herbal Drugs in Benign Prostrate Hyperplasia (BPH) in India: A Current Update ", and found it the majority of the studied patients were using Ginger and Aloe Vera in the treatment of prostate symptoms and considered it as natural antibiotic.

The present study clarified that there were highly statistically significant relations between the studied patients' total lifestyle score and their voiding habits after prostatectomy $(\mathrm{P}<0.001)$. From the researchers' point of view, this may be because the healthy lifestyle usually leads to healthy voiding habits and the opposite is true. This result was in the same line with Mina et al. (2015), they performed a study about "Physical Activity and Quality of Life after Radical Prostatectomy in Canada", and found that there were highly statistically significant relations between the studied patients' total lifestyle score and their voiding habits after prostatectomy.

The same results were against the results of Wilson et al. (2016), they conducted study about "Risk of Urinary Incontinence Following Prostatectomy in Holland: The Role of Physical Activity and Obesity", and found that there were no statistically significant relations found between the studied patients' total lifestyle score and their voiding habits after prostatectomy.

There were highly statistically significant positive correlations between the studied patients' voiding habits and their lifestyle characteristics related to dietary habits, smoking habits, personal hygiene, stress, and sexual practices. While there were no statistically positive correlations between the studied patients' voiding habits and their activities as well as exercises, sleep and comfort. From the researchers' point of view, the healthy lifestyles always have a positive effect on the health of any person and the opposite is true.

These results were in the same line with Cohen \& Jefferies (2018), they performed a study about "Supporting Patients During and After Prostate Cancer Treatment: Evidence-Informed Approach to Lifestyle and Behavior Change ", and found that there were highly statistically significant positive correlations between the 
studied patients' voiding habits and their lifestyle characteristics related to dietary habits, smoking habits, personal hygiene, stress, and sexual practices. While disagreed with these results as there were also highly statistically significant positive correlations between the studied patients' voiding habits and their activities exercises, sleep and comfort.

The same results were against the results of Babic et al. (2015), they performed a study about "Impact of Voiding and Incontinence Symptoms on Health-Related Quality of Life in Serbian Male Population with Prostate Cancer", and found that there were highly statistically positive correlations between the studied patients' voiding habits and all the domains of lifestyle.

\section{Conclusion}

There were highly statistically significant differences in all items related the studied patients' voiding habits between pre and postoperative. There were highly statistically significant positive correlations between the studied patients' voiding habits and their lifestyle characteristics related for dietary habits, smoking habits, personal hygiene, stress, and sexual practices. While there were no statistically positive correlations between the studied patients' voiding habits and their activities as well as exercises, sleep and comfort.

\section{Recommendations}

-Conducting a study on the aspects of patients' knowledge, attitude, and practices towards prostate tumor.

-Establishing of an educational program for improve health related quality of life for prostate tumor patients.
-Another study should be done on the aspect of preventing prostate tumor complications.

-Prostatectomy follow-up guidelines should be developed for patients by prostate tumor.

-The same study should be replicated for a large sample size from different geographical areas for generalize the results.

\section{References}

Ahn, T., Roberts, M., Strahan, A., Malone, G., Paterdis, J., Wood, G., and Heathcote, P. (2019). Improved Lower Urinary Tract Symptoms After Robot-assisted Radical Prostatectomy: Implications for Survivorship, Treatment Selection and Patient Counselling in Australia. BJU International Journal; 123(5): PP. 47-53. doi:10.1111/bju.14717.

Babic, U., Santric-Milicevic, M., Terzic, Z., and Vukotic, V. (2015): Impact of Voiding and Incontinence Symptoms on Health-Related Quality of Life in Serbian Male Population with Prostate cancer. Urology Journal; 12(3): PP.2196-203.

Canadian Cancer Society, (2021): The prostate. Available at: https://www.cancer.ca/en/cancerinformation/cancer-type/prostate/prostatecancer/the-prostate/?region=on. Accessed on 15 January 2021.

Chin, S., Hayden, A., Gebski, V., Cross, S., and Turner, S. (2017): Long Term Patient Reported Urinary Function Following External Beam Radiotherapy for Prostatic Cancer Patients in England. Clinical Oncology Journal; 29(4): PP.421-8. doi: 10.1016/j.clon.2017.01.043.

Cohen, L., and Jefferies, A. (2018): Supporting Patients During and After Prostate 
Cancer Treatment: Evidence-Informed Approach to Lifestyle and Behavior Change. Available at: https://ascopost.com/issues/may25-2018/evidence-informed-approach-tolifestyle-and-behavior-change/. Accessed on 15 January 2021.

James, P., Debra, J., Michaela, E., Rosebud, O., Cynthia, J., Michael, M., and Steven, J. (2016): Association of Anthropometric Measures with the Presence and Progression of Benign Prostatic Hyperplasia in Minnesota. American Journal of Epidemiology; 164(1): PP. 41-46. https://doi.org/10.1093/aje/kwj151.

Ferlay J, Soerjomataram I, Ervik M, et al. F.Globocan (2018): Cancer Incidence and Mortality Worldwide: IARC Cancer Base No 11 [webpage on the Internet]. Lyon, France: International Agency for Research on Cancer;2018.Available from: http:// globocan.iarc.fr/Pages/fact_sheets_cancer.aspx Fujita, K., Hayashi, T., Matsushita, M., Uemura, M., and Nonomura, N. (2020): Obesity, Inflammation, and Prostate Cancer. Journal of Clinical Medicine; 8 (201): PP.21. https://doi.org/10.3390/jcm8020201.

Liu, D., Kuai, Y., Zhu, R., Zhou, C., Tao, Y., Han, W., and Chen, Q. (2020): Prognosis of Prostate Cancer and Bone Metastasis Pattern of Patients: a Local Hospital Based Study from China. Scientific Report 10 9104; https://doi.org/10.1038/s41598-020-64073-6

Mandal, A. (2020): Prostate cancer complications. Available at: https://www.newsmedical.net/health/Prostate-cancercomplications.aspx. Accessed on 29 December 2020.

Mei, W., Lin, X., Kapoor, A., Gu, Y., Zhao, K., and Tang, D. (2020): The Contributions of Prostate Cancer Stem Cells in Prostate Cancer
Initiation and Metastasis. Cancers; 11 (434): PP.22.doi:10.3390/cancers11040434.

Rawla, P. (2020): Epidemiology of prostate cancer. World Journal of Oncology; 10 (12): PP.63. Doi: 10.14740/wjon1191.

Stephen, W., Taylor, L., Sajjad, S., and Siref, L. (2020): Prostate cancer. Availalable at: https://www.ncbi.nlm.nih.gov/books/NBK4705 50/. Accessed on 29 December 2020.

Saxena, V., Srivastava, N., and Pandey, N. (2020): Herbal Drugs in Benign Prostrate Hyperplasia (BPH) in India: A Current Update. International Journal of Pharmaceutical Sciences and Research; 11(2): PP.580-86. doi: 10.13040/IJPSR.0975-8232.11(2).580-86.

Tracy, C., \& Kim, E. (2020): Prostate Cancer Clinical Presentation. Available at: https://emedicine.medscape.com/article/196773 1-clinical. Accessed on 12 January 2021.

Wilson, K., Markt, S., Fang, F., Nordenvall, C., Rider, J., Ye, W., Adami, H., Stattin, P., Nyrén, O., and Mucci, L. (2016): Snus use, smoking and survival among prostate cancer patients in Swed. International Journal of Cancer; 139(12): PP. 2753-2759.doi: 10.1002/ijc.30411. 


\section{تقييم عادات التبول قبل وبعد الجراحة بين المرضى الأين يخضعون لعملية استئصال البروستاتا ريهام حنفي محمود- زينب حسين علي- منال حامد محمود ـ أمل سعيد طه}

ويعد استئصال البروستاتا إجراء شائع لإزالة غدة البروستاتا وذلك لعلاج سرطان البروستاتا الغدي في أغلب الأحيان بالر غم من إجر ائه أحيانًا لتضخم البروستاتا الحمبد. لذلك هدفت هذه الدراسة إلى تقييم عادات التبول قبل وبعد الجراحة بين المرضى الذين يخضعون لعملية استئصسال البروستاتا. حيث تم استخدام التصميم الوصفي للبحث في إجراء هذه الدراسة. و أجريت الدراسة في مستثفى جامعة بنها بقسم جراحة المسالك البولية. على 0 ـ 1 مريضا خضعو العملية استئصسال البروستاتا. ولخصت الدراسة بوجود فروق ذات دلالة إحصائية عالية في جميع البنود المتعلقة بعادات التبول لدى المرضى الخاضعين للار اسة بين ما قبل الجراحة وبعدها. كانت هنالك ارتباطات إيجابية ذات دلالة إحصائية عالية بين عادات إفراغ المرضى الخاضعين للار اسة وخصائص نمط حياتهم المتعلقة بالعادات الغذائية وعادات التدخين والنظافة الثخصية والإجهاد والممارسات الجنسية. بينما لا توجد علاقة ذات دلالة إحصائية بين عادات التبول لدى المرضى و أنثطتهم وكذلك التمارين والنوم و الراحة. كما أوصت الدر اسة بوضع برنامج تعليمي لتحسين نوعية الحياة المتعلقة بالصحة لمرضى سرطان البروستاتا. 